\title{
THE DETERMINANTS OF SPENDING BY BILTONG HUNTERS
}

P Van der Merwe, M Saayman and W Krugell

School of Entrepreneurship, Marketing and Tourism Management Institute for Tourism and Leisure Studies School of Economics, North-West University

\begin{abstract}
According to a national survey conducted in 2005, biltong hunters contribute significantly to conservation and the South African economy. This research indicated that the economic contribution of biltong hunting is just over R3 billion (US\$ 500 million) per season. The aim of this article is to establish the determinants of biltong hunters' spending in South Africa. This information could be used to increase spending by biltong hunters on tailor-made packages.

The sample population included all members of the SA Hunters and Game Conservation Association. A regression analysis was undertaken to identify the determinants of spending by biltong hunters. The main findings of the research indicated that income, number of game items hunted, number of days spent hunting and distance travelled are the main determinants.
\end{abstract}

JEL D12

\section{1}

\section{Introduction and problem statement}

Foreign tourist arrivals to South Africa are a good indicator of the growth in tourism. These arrivals increased from 5.87 million in 2000 to 7.5 million in 2005. The percentage increase for 1995 to 2004 was 48.7 per cent (South Africa Annual Tourism Report, 2004). Naturebased tourism is attracting increasing interest from governments, the tourism industry and researchers alike. Tourism activities include whale-watching, going on safaris, bird-watching, fishing and hunting, amongst others. According to Higginbottom (2004), nature-based tourism is widely considered to be a growth sector and could contribute substantially to the economy of the host country. Mottiar (2006) maintains that tourist expenditure is the clearest indication of the economic benefits of tourism for an area, and is certainly the most important contribution.

A large percentage of nature-based tourism in South Africa takes place on game farms, which cover 17.9 per cent of the total land suitable for agricultural use in South Africa. This translates into 14.7 million ha (6 330 exempted game farms), compared to 3 per cent of land (3.7 million ha) officially protected by SANParks management (Van Hoven, 2005). One of the main sources of income for game farms is biltong hunting (Van der Merwe, Saayman \& Krugell, 2004). The most popular province for hunting (37 per cent) is the Limpopo Province, which is situated in the north of the country, bordering Botswana and Zimbabwe. Saayman, Saayman and Naudè (2000) identified the following economic benefits of development in the hunting industry:

- Hunting is exportable.

- Hunting generates income.

- Hunting creates job opportunities.

- Hunting generates foreign exchange.

- Hunting encourages entrepreneurship.

- Hunting creates infra- and supra-structures.

According to Saayman and Van der Merwe (2006), the contribution of biltong hunters to the economy of South Africa is just over R3 billion (US\$ 500 million) per season. Most biltong 
hunting is conducted in rural areas, so hunting is a major contributor to the economy of rural provinces. This finding is supported by De Seixas (2006), who indicates that hunting conducted in Portugal in the Baixo Alentejo region, a rural area, is viewed as a method of increasing economic growth. Kastenholz (2005) adds that visitor spending is 'one of the most critical variables of analysis for tourist destinations, as it directly determines the tourism industry's (sector) profitability'. In order to increase the spending by biltong hunters, however, it is important to establish the determinants of spending.

Researchers like Mok and Iverson (2000); Narayan (2003); Letho, Cai, O'Leary and Huan (2004); Kastenholz (2005) and Saayman and Saayman (2006) indicate the following reasons for the importance of establishing the determinants of spending. The information can assist hunters, game farm owners and policymakers alike in:

- destination marketing,

- proposed alternative policies,

- sustainable product development,

- retail merchandising,

- customer service,

- defining markets, and

- creating better understanding of the industry

The aim of this paper is to establish the determinants of the spending by biltong hunters. Based as it is on the application of the information on the hunting industry, this research could assist marketers, hunting operators and the tourism industry in general. In order to achieve the latter, the paper is structured in the following manner: a literature review, a description of the survey and a discussion of results and, finally, the regression analysis of the determinants of spending by biltong and hunters is discussed.

\section{2 \\ Literature review}

In an attempt to understand the hunting sector, Van der Merwe, Saayman and Krugell (2006) compiled a value chain for a hunting trip. This makes it possible to see clearly where money is spent during the hunting trip and where value could be added in an enhancement of the experience. The value chain starts with booking accommodation and the game to be hunted. Preparation for a hunt is the second line of spending. Hunters spend money on ammunition, equipment, clothing, firearm licensing, shooting preparations, hunting permits and association fees. The third line of spending is the transportation to and from the destination and includes fuel, food, beverages and souvenirs. Fourth, and probably largest, is expenditure at the destination, where hunters pay for the game they have hunted, accommodation, food, drinks and services rendered by the game farm. The final line of spending is back at home, where hunters pay for the meat processing, taxidermy services and the replacement of lost or broken equipment (Figure 1). 
Figure 1

Value Chain - Hunting trip

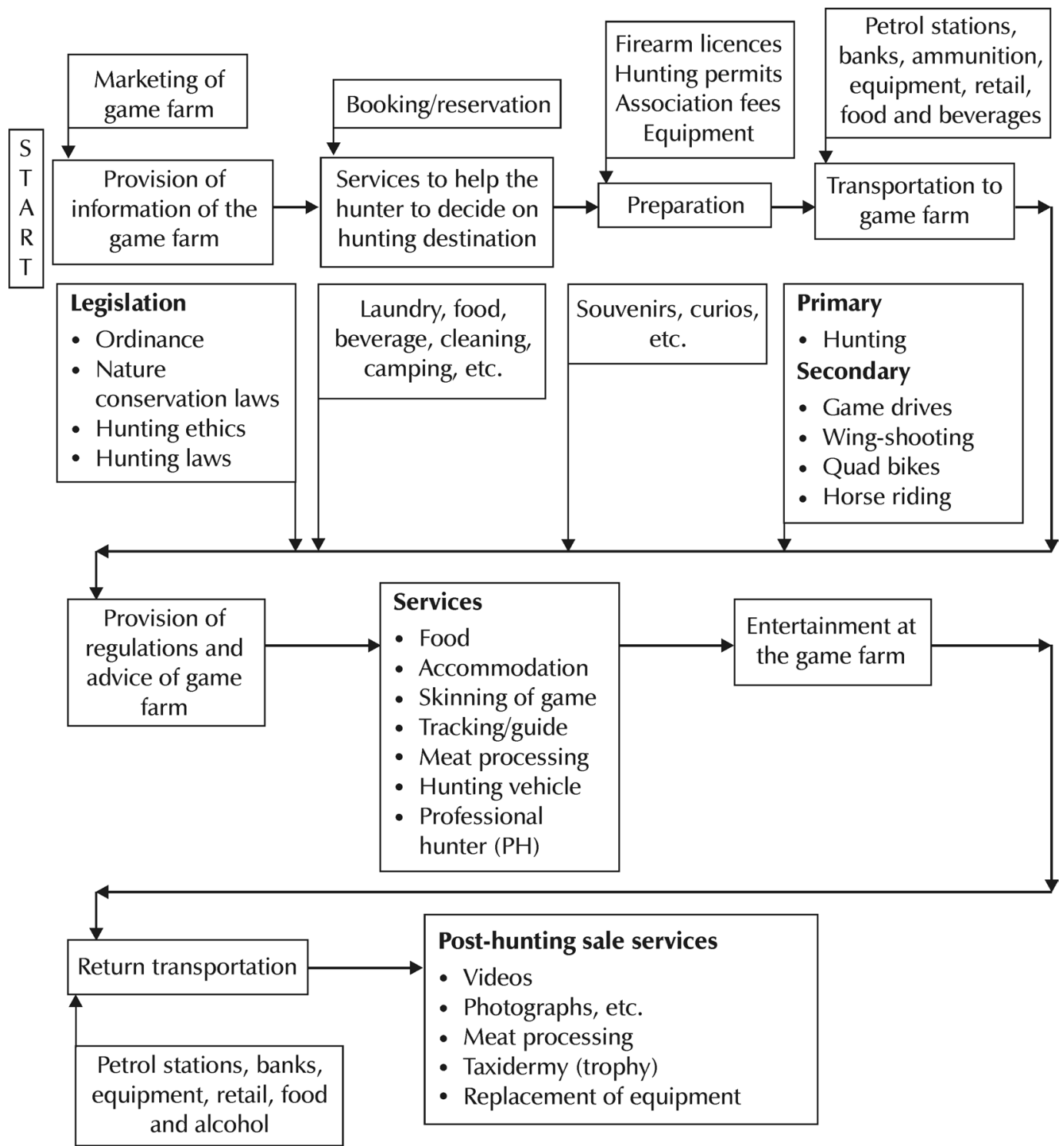

(Source: Van der Merwe et al., 2006)

The largest expenditure during the hunting trip is on the animals hunted; this figure represents approximately 60 per cent of the total expenditure (Table 2). It is evident from research conducted by Van Heerden, (2003), Du Plessis (2004), Pissoort (2007) and Saayman, Saayman and Rhodes (2001) that different tourist types have different spending patterns. It can therefore be assumed that the determinants of group spending are also going to differ. Kastenholz (2003) argues that tourist spending is one of the most critical variables in analysing a tourist destination, because it directly determines the tourism sector's profitability. Narayan (2003) used determinants of tourist expenditure to help politicians in Fiji understand their industry better.

Numerous researchers have conducted research on the determinants of spending and the information has been used for various ends, such as destination marketing, niche marketing, 
product development, policy formulation, retail merchandising and customer service. Perez and Juaneda (2000), Seiler, Hsieh, Seiler and Hsieh (2002), Lee (2001), Jang, Bai, Hong, and O'Leary (2004); Cannon and Ford (2002) and Downward and Lumdson (2002) found, in their respective studies, that expenditure levels are dependent on socio-demographics, but specifically on educational levels, professional status and available income. Cannon and Ford (2002) demonstrated that the place of residence (expenditure levels increase for visitors from out-of-state) and group size (Downward \& Lumdson, 2003; Skuras, Dimara \& Petrou, 2005) had a positive relation to expenditure. The role of age was not conclusive in certain studies: for example, Perez and Juaneda (2000), Jang, Bai, Hong and O'Leary (2004), Mok and Iverson (2000), Kastenholz (2005), Saayman and Saayman (2006) and Letho et al. (2004) all found a positive correlation between age and total expenditure levels, while Mudambi and Baum (1997) indicated an inverse relationship between age and total expenditure. Davies and Mangan (1992), Crouch (1994), Fish and Waggle (1996), Agarwal and Yochum (1999), Van der Lans, Van Ittersum, De Cicco and Loseby (2001), Dimara and Skuras (2003) and Letho et al. (2004)) indicated that income, duration of stay, gender and language have a positive impact on the spending by tourists. According to Sakai (1988), Mok and Iverson (2000), and Letho et al. (2004), the purpose for travelling has a significant impact on the spending pattern, with business travellers exhibiting the greatest spending and the most expensive travel style (Letho et al., 2004).

Duration of stay was shown to correlate positively with overall expenditure levels (Seiler et al., 2002; Downward \& Lumdson, 2003; Jang et al., 2004; Mok \& Iverson, 2000; Kastenholz, 2005). Downward and Lumdson (2003) found that decreased spending per day was related to a longer duration of stay. Jang et al. (2004) showed that first-time visitors spend more than repeat visitors, although the overall benefit of repeat visits should not be ignored in this context.

Bahar, Kazak and Gokovali (2006) have divided research on spending into three categories, namely
- calculating the average amount spent per tourist per vacation,

- estimating the per person spending on a daily basis, and

- categorisation of tourists according to how much they spend in total.

These categories are then used as dependent variables. In order to get a holistic picture, all variables of tourist spending should be identified; the last category is therefore recommended by these researchers.

The literature review above clearly shows that different activities/attractions and types of tourists have different determinants of spending. Therefore, the question to be answered is: What are the determinants of the spending by biltong hunters?

3

\section{Method of research}

In 2004, a pilot study comprising 87 questionnaires was conducted in the North West Province. Amendments were made to the questionnaire and a national survey was conducted in July 2005. The national survey was based on all the members $(\mathrm{N}=17066)$ of the South African Hunters and Game Conservation Association (SA Hunters). This is one of the largest hunting associations recognised by the South African government. Questionnaires accompanying their monthly magazine were mailed to the members of the SA Hunters and Game Conservation Association. Reminders were sent during August 2005. Respondents were requested to return the completed questionnaires by mail, e-mail or fax. A total of $1024(\mathrm{~N}=1024)$ questionnaires were returned, resulting in a 6 per cent return rate. The statistical analysis included descriptive statistics as well as a regression analysis.

\subsection{Results}

The result of the survey describes first the profile of a biltong hunter (see Table 1) and the associated expenditures. This is followed by a regression analysis. Based on the information below, most hunters are male and most are Afrikaans speaking. 
These hunters' average spending per person per season is R15 752.37 (see Table 2), of which R4 130.00 is spent on general expenses.

\section{Table 1}

Profile of biltong hunters

\begin{tabular}{|l|l|}
\hline CATEGORY & RESULTS \\
\hline Gender & $98 \%(1003)$ male \\
\hline Language & $87 \%(891)$ Afrikaans \\
\hline Age & $63 \%(645)$ between 40 and 64 years of age \\
\hline Marital status & $89 \%(911)$ married \\
\hline Level of education & $69 \%(707)$ have some form of post-matric qualifications \\
\hline Occupation & $22 \%(225)$ self-employed; $18 \%$ (184) admin. \& 18\% (184) manager \\
\hline Income & $48 \%(492)$ earn more than R250 000 per annum \\
\hline Prefer to hunt & $68 \%$ (706) hunt in group (average size 4 persons) \\
\hline Number of hunting trips & 3 times a year \\
\hline Preferred provinces & Lim. (37\%, or 379), NC (15\%, or 154) and NW (14\%, or 143) \\
\hline Average length of stay & 4 days \\
\hline Average number of species hunted & 5 species \\
\hline Main reason for hunting & Biltong \\
\hline
\end{tabular}

$(\operatorname{Lim}=$ Limpopo; NC = Northern Cape; NW = North West $)$

Based on the median (per species), the average hunter would hunt at least five different species per year/season and spend an average of R11 622.37 per season on game. The total amount spent by biltong hunters per season is therefore R15 752.37 per hunter.

Table 2

Average expenses

\begin{tabular}{|l|c|}
\hline Category & Total expenditure per season in rands \\
\hline Accommodation & 869 \\
\hline Fuel & 734 \\
\hline Food & 452 \\
\hline Meat processing & 417 \\
\hline Ammunition & 279 \\
\hline Hunting gear & 278 \\
\hline Daily fees & 260 \\
\hline Alcohol and beverages & 245 \\
\hline Butcher facilities & 229 \\
\hline Clothing & 139 \\
\hline
\end{tabular}




\begin{tabular}{|l|c|}
\hline Other & 102 \\
\hline Medicine & 54 \\
\hline Toiletries & 51 \\
\hline Tobacco & 21 \\
\hline Expenses: excluding game & $\mathbf{4 1 3 0 . 0 0}$ \\
\hline Game expenses & $\mathbf{1 1 6 2 2 . 3 7}$ \\
\hline Total spending & $\mathbf{1 5 7 5 2 . 3 7}$ \\
\hline
\end{tabular}

4

\section{Regression analysis of the determinants of the spending by biltong hunters}

The previous section described the data obtained in the survey. This has already provided some insight into the characteristics of the biltong hunters and their spending. It was pointed out that the respondents are mainly male, Afrikaansspeaking and married. They fall into different age groups and occupations and have different preferences when it comes to hunting. Some stay longer than others, and some prefer to hunt in groups. It is to be expected that hunters who stay longer or who go hunting more often would spend more. Simple correlations also show a positive correlation between expenditure on biltong hunting and income, and a negative correlation between expenditure on biltong hunting and age. However, such analyses do not describe the relative strength or the significance of the relationship between spending and its different determinants. Such an examination requires a regression analysis.

\subsection{The estimating equation and explanatory variables}

This section presents the results of the estimation of a regression model of the determinants of the spending by biltong hunters. The model is a simple linear regression of total spending on a number of quantitative and qualitative determinants of spending. The estimating equation can be expressed as follows:

$Y_{i}=c+\beta X_{i}+u_{i}$

in which $\mathrm{Y}_{\mathrm{i}}$ represents the total spending by a biltong hunter and $\mathrm{X}_{\mathrm{i}}$ is a vector of the determinants of spending. These explanatory variables may include quantitative variables like income, the number of days spent hunting, the number of hunting trips per season, the distances driven or the number of game hunted. It may also include qualitative variables that indicate the presence or absence of a quality or attribute which may influence total spending on biltong hunting. Such qualitative (or dummy) variables may include age, gender, language, marital status, education and occupation. Table 3 lists the explanatory variables which were included in different versions of the model and their expected correlation to total spending.

Table 3

The explanatory variables in the regression model

\begin{tabular}{|l|l|}
\hline Explanatory variable & Expected correlation to total spending by biltong hunters \\
\hline Income & $\begin{array}{l}\text { Positive correlation - biltong hunting is expected to be a normal good } \\
\text { and hunters with more income will spend more on hunting }\end{array}$ \\
\hline Number of game hunted & Positive correlation \\
\hline Number of days spent hunting & Positive correlation \\
\hline Number of hunting trips per season & Positive correlation \\
\hline
\end{tabular}


Table 3

The explanatory variables in the regression model (continued)

\begin{tabular}{|l|l|}
\hline Explanatory variable & Expected correlation with total spending by biltong hunters \\
\hline Distance driven & Positive correlation - hunting in more remote locations incurs greater cost \\
\hline Age & $\begin{array}{l}\text { Not clear - older hunters may earn more discretionary income than } \\
\text { younger ones, but retired hunters will have only a fixed income and may be } \\
\text { more price sensitive than younger ones }\end{array}$ \\
\hline Gender & A priori it is not clear whether male or female hunters would spend more \\
\hline Language & $\begin{array}{l}\text { A priori it is not clear whether being Afrikaans speaking or not is positively } \\
\text { or negatively related to spending on biltong hunting }\end{array}$ \\
\hline Marital status & $\begin{array}{l}\text { Not clear - hunters who are not married may have more discretionary } \\
\text { income, but those who are married have the benefit of a double income } \\
\text { household }\end{array}$ \\
\hline Education & $\begin{array}{l}\text { One would expect better-educated hunters to earn more and thus be able } \\
\text { to spend more }\end{array}$ \\
\hline $\begin{array}{l}\text { Preference for hunting in a } \\
\text { group, or not }\end{array}$ & $\begin{array}{l}\text { A negative correlation may be expected - sharing transport and } \\
\text { accommodation reduces spending by the individual hunter }\end{array}$ \\
\hline
\end{tabular}

\subsection{The estimation strategy}

The estimation strategy involves estimating a log-linear model using the cross-section data obtained in the survey. The quantitative variables are logged, because this compresses the scales in which the variables are measured. It also allows the coefficients to be interpreted as partial elasticity coefficients. An ordinary least squares (OLS) estimator is used. However, because cross-section data is typically subject to the problem of heteroscedasticity, it has to be accounted for. A White test was done on initial results and it was found that the null hypothesis of no heteroscedasticity was rejected. The results reported thus present White's heteroscedasticity-corrected standard errors.

\subsection{The results}

The following table (Table 4) presents the estimation results.
Table 4 shows the results of six different versions of the model. The first, base-case version of the model includes only quantitative variables, examining the relationship between the total spending by biltong hunters and income, the number of days spent hunting and the number of times they went hunting per season. The model finds the anticipated positive correlations, and the coefficients are significant at the 5 per cent level. Because the coefficients are partial elasticity coefficients, they can be interpreted as follows: for a 1 per cent increase in income, total spending on biltong hunting goes up by 0.23 per cent (retaining the influence of the number of days the hunters stay and the number of times they go hunting constant). In model (1), income, the number of days spent hunting and the number of times the biltong hunters went hunting explain 27 per cent of the variation in total spending. 
Table 4

Regression results

\begin{tabular}{|c|c|c|c|c|c|c|}
\hline \multicolumn{7}{|c|}{ Dependent variable: Total spending by biltong hunters } \\
\hline $\begin{array}{l}\text { Explanatory } \\
\text { variables }\end{array}$ & $\begin{array}{l}\text { (1) } \\
\text { Base-case }\end{array}$ & $\begin{array}{l}(2) \\
\text { Best-case }\end{array}$ & $\begin{array}{l}\text { (3) } \\
\text { Best }+ \\
\text { gender } \\
\text { dummy }\end{array}$ & $\begin{array}{l}\text { (4) } \\
\text { Best + age } \\
\text { dummy }\end{array}$ & $\begin{array}{l}\text { (5) } \\
\text { Best }+ \\
\text { education } \\
\text { dummy }\end{array}$ & $\begin{array}{l}\text { (6) } \\
\text { Best }+ \\
\text { group } \\
\text { dummy }\end{array}$ \\
\hline Constant & $\begin{array}{c}5.239 \\
(0.361)\end{array}$ & $\begin{array}{l}5.036 \\
(0.278)\end{array}$ & $\begin{array}{l}5.220 \\
(0.322)\end{array}$ & $\begin{array}{l}5.545 \\
(0.401)\end{array}$ & $\begin{array}{l}5.035 \\
(0.283)\end{array}$ & $\begin{array}{l}5.145 \\
(0.307)\end{array}$ \\
\hline Income & $\begin{array}{c}0.238 \\
(0.029)^{*}\end{array}$ & $\begin{array}{c}0.114 \\
(0.020)^{*}\end{array}$ & $\begin{array}{l}0.116 \\
(0.020)^{*}\end{array}$ & $\begin{array}{l}0.101 \\
(0.022)^{*}\end{array}$ & $\begin{array}{c}0.114 \\
(0.021)^{*}\end{array}$ & $\begin{array}{l}0.107 \\
(0.022)^{*}\end{array}$ \\
\hline $\begin{array}{l}\text { Number of } \\
\text { game hunted }\end{array}$ & & $\begin{array}{c}0.657 \\
(0.021)^{*}\end{array}$ & $\begin{array}{l}0.656 \\
(0.022)^{*}\end{array}$ & $\begin{array}{c}0.657 \\
(0.023)^{*}\end{array}$ & $\begin{array}{c}0.657 \\
(0.022)^{*}\end{array}$ & $\begin{array}{l}0.620 \\
(0.024)^{*}\end{array}$ \\
\hline $\begin{array}{l}\text { No of days } \\
\text { hunting }\end{array}$ & $\begin{array}{c}0.654 \\
(0.059)^{*}\end{array}$ & $\begin{array}{c}0.246 \\
(0.043)^{*}\end{array}$ & $\begin{array}{l}0.245 \\
(0.043)^{*}\end{array}$ & $\begin{array}{l}0.238 \\
(0.045)^{*}\end{array}$ & $\begin{array}{c}0.246 \\
(0.043)^{*}\end{array}$ & $\begin{array}{l}0.278 \\
(0.050)^{*}\end{array}$ \\
\hline $\begin{array}{l}\text { No of times } \\
\text { hunting }\end{array}$ & $\begin{array}{l}0.373 \\
(0.038)^{*}\end{array}$ & & & & & \\
\hline Distance & & $\begin{array}{c}0.179 \\
(0.025)^{*}\end{array}$ & $\begin{array}{c}0.180 \\
(0.024)^{*}\end{array}$ & $\begin{array}{l}0.190 \\
(0.027)^{*}\end{array}$ & $\begin{array}{l}0.179 \\
(0.025)^{*}\end{array}$ & $\begin{array}{l}0.175 \\
(0.028)^{*}\end{array}$ \\
\hline Language & & $\begin{array}{l}-0.116 \\
(0.047)^{*}\end{array}$ & $\begin{array}{l}-0.113 \\
(0.047)^{*}\end{array}$ & $\begin{array}{l}-0.154 \\
(0.052)^{*}\end{array}$ & $\begin{array}{l}-0.116 \\
(0.047)^{*}\end{array}$ & $\begin{array}{l}-0.069 \\
(0.054)\end{array}$ \\
\hline Marital status & & $\begin{array}{c}0.101 \\
(0.054)^{*}\end{array}$ & $\begin{array}{c}0.098 \\
(0.054)\end{array}$ & $\begin{array}{l}0.166 \\
(0.061)^{*}\end{array}$ & $\begin{array}{c}0.101 \\
(0.054)^{*}\end{array}$ & $\begin{array}{l}0.129 \\
(0.059)^{*}\end{array}$ \\
\hline Gender & & & $\begin{array}{l}-0.210 \\
(0.185)\end{array}$ & & & \\
\hline Age & & & & $\begin{array}{l}-0.115 \\
(0.068)\end{array}$ & & \\
\hline Education & & & & & $\begin{array}{r}-0.0007 \\
(0.034)\end{array}$ & \\
\hline $\begin{array}{l}\text { Group dummy* } \\
\text { Group size }\end{array}$ & & & & & & $\begin{array}{l}-0.017 \\
(0.038)\end{array}$ \\
\hline $\operatorname{adj} \mathbf{R}^{2}$ & 0.27 & 0.65 & 0.65 & 0.64 & 0.65 & 0.63 \\
\hline
\end{tabular}

The results for model (2) are the best and were obtained for different combinations of the explanatory variables. Again, the quantitative variables are interpreted as partial elasticity coefficients. The results indicate that, for a 1 per cent increase in income, total spending on biltong hunting will increase by 0.11 per cent. For a 1 per cent increase in the number of game hunted, total spending will increase by 0.65 per cent. Thus, income, the number of game hunted, the number of days stayed and the distance driven by the hunters all are positively and significantly linked to total spending. The regression also includes two qualitative variables: language and marital status. The dummy variable was defined so that Afrikaans- 
speakers $=1$ and all other languages $=0$. The result shows that, if everything else is kept constant, the average Afrikaans-speaking hunter spends 11 per cent less than hunters who are not Afrikaans-speaking. Similarly, the marital status dummy was defined as: married hunters $=1$ and all others $=0$. The coefficient shows that the average married hunter spends 10 per cent more than a hunter who is not married, when everything else is kept constant. This best-case model explains 65 per cent of the variation in total spending.

Models (3) to (6) show the best-case model combined with additional qualitative variables. Obviously this does not make much difference to the results. Model (3) adds a dummy variable for the males. Keeping everything else constant, the males seem to spend 21 per cent less than female hunters. However, the coefficient is insignificant at the 5 per cent level and the marital status dummy now also becomes insignificant. Model (4) adds the age of the hunters to the regression and the partial elasticity coefficient indicates that, for a 1 per cent increase in age, total spending on biltong hunting decreases by 11.5 per cent. However, this coefficient is insignificant. An education dummy is added in model (5). The variable was defined so that hunters with a degree, diploma or postgraduate qualification $=1$ and all others $=0$. Keeping everything else constant, the hunters with higher qualifications seem to spend 0.07 per cent less than those who do not have similar qualifications. Once again, the coefficient is insignificant. Finally, model (6) accounts for the influence of whether a hunter prefers to hunt alone or in a group. A dummy variable for this preference (group $=1$ and alone $=0$ ) was multiplied by the group size. Again, keeping everything else constant, the hunters who prefer to hunt as part of a group seem to spend 1.6 per cent less than those who prefer to hunt alone, but the coefficient is insignificant.

More combinations were tried in all categories, but no robust results were found to show age, gender or education to be a significant determinant of the spending by biltong hunters.

\section{5}

\section{Conclusions and recommendations}

The determinants that showed a positive correlation with spending are the income of hunters, the length of stay, the number of hunting trips, the distance travelled, language, marital status, gender and whether hunters travel alone or in groups. The determinants with the strongest correlation are income, the number of game hunted the number of days stayed and the distance travelled.

To a certain extent, this research supports numerous other studies, but it also contradicts the findings of certain others. A result of interest is that age is not a determinant, which is contrary to the findings of Mok and Iverson (2000), Perez and Juaneda (2000), Kastenholz (2005) and Saayman and Saayman (2006) but similar to the findings of Mudambi and Baum (1997). Results from this research also contradict research done by Seiler et al. (2002), Jang et al. (2004) and Cannon and Ford (2002), who found that the level of education is not a determinant. Another interesting determinant is the distance travelled, which does not feature in any research mentioned above. As far as gender as a determinant is concerned, this research supports other research (Grouch, 1994; Fish \& Waggle, 1996) that found that females tend to spend more than males, even though hunting is predominantly an activity practised by males. This finding was most unexpected.

Hence, findings were made that clearly differ from those of similar research carried out among other types of tourists. These determinants could be used to increase the spending by biltong hunters, thereby creating a greater economic impact. It could also be used for marketing purposes. For example, spending could be increased significantly by increasing the number of days as well as the number of species hunted. This could be done by offering hunters different packages, including family packages or packages with a greater variety of species. The packages could also be used to attract hunters to less popular destinations. Based on this research, it is recommended that a similar study be conducted on trophy hunting (international hunters). It is 
also recommended that research be conducted on the demand by hunters for different species, focusing on both domestic and international hunters and on how this impacts on the price of game.

\section{References}

1 ARGARWAL, V.B. \& YOCHUM, G.R. (1999) "Tourism spending and race of visitors", Journal of Travel Research, 38(2): 173-176.

2 BAHAR, O.; KAZAK, M. \& GOKOVALI, U. (2006) "Estimating the determinants of tourist spending", paper presented at the Second International Tourism Economics Conference, 18 -20 May, Palma.

3 CANNON, T.F. \& FORD, J. (2002) "Relationship of demographic and trip characteristics to visitor spending: an analysis of sports travel visitors across time", Tourism Economics, 8(3): 263-271.

4 CROUCH, G. (1994) "The study of international tourism demand: a review of findings", Journal of Travel Research, 33(1): 12-23.

5 DAVIES, B. \& MANGAN, J. (1992) "Family expenditure on hotels and holidays", Annals of Tourism Research, 19(4): 691-699.

6 DE SEIXAS, A.F.S. (2006) "Hunting tourism in the region of Baixo Alentejo" paper presented at the Theoretical Advances in Tourism Economic, 18-19 March, Evora.

7 DIMARA, E. \& SKURAS, D. (2003) "Consumer evaluation of product certification, geographic association and traceability in Greece", European Journal of Marketing, 80: 466-473.

8 DOWNWARD, P.M. \& LUMDSON, L. (2002) "Beyond the demand for day-visits", Tourism Economics, 9(1): 67-76.

9 DU PLESSIS, C. (2004) "The economic impact of the 2003 cricket world cup on Potchefstroom", Masters dissertation, North-West University: Potchefstroom.

10 FISH, M. \& WAGGLE, D. (1996) "Current income versus total expenditure measure in regression models of vacational and pleasure travel", Journal of Travel Research, 35(2): 70-74.

11 HIGGINBOTTOM, K. (2004) "Wildlife tourism: an introduction", in K. Higginbottom (ed.) Australia: Wildlife Tourism: Impacts and Planning, Common Ground Publishing: Altona Vic.

12 JANG, S.; BAI, B.; HONG, G. \& O'LEARY, J.T. (2004) "Understanding travel expenditure patterns: A study of Japanese pleasure travellers to the United States by income level", Tourism Management, 25(3): 331-341.
13 KASTENHOLZ, E. (2005) "Analysis determinants of visitor spending for the rural tourist market in North Portugal”, Tourism Economics, 11(4): 555569.

14 LEE, H.C. (2001) "Determinants of recreational boater expenditure on trips", Tourism Management, 22(6): 659-667.

15 LETHO, X.Y.; CAI, L.A.; O’LEARY, J.T. \& HUAN, T.C. (2004) "Tourist shopping preferences and expenditure behaviours: the case of the Taiwanese outbound market", Journal of Vacation Marketing, 10(4): 320-332.

16 MOK, C. \& IVERSON, T.J. (2000) "Expenditurebased segmentation: Taiwanese tourists to Guam", Tourism Management, 21(3): 299-305, June.

17 MOTTIAR, Z. (2006) "Holiday home owners, a route to sustainable tourism development? An economic analysis of tourist expenditure", Journal of Sustainable Tourism, 14(6): 582-599.

18 MUDAMBI, R. \& BAUM, T. (1997) "Strategic segmentation: an empirical analysis of tourist expenditures in Turkey", Journal of Travel Research, 36(1): 29-34.

19 NARAYAN, P.K. (2003) "Determinants of tourist expenditure in Fiji: a co-integration approach", Pacific Tourism Review, 6(3-4): 159-167.

20 PEREZ, E.A. \& JUANEDA, S.C. (2000) “Tourism expenditure for mass tourism markets", Annals of Tourism Research, 27(3): 627-637, July.

21 PISSOORT, V. (2007) "Visitor profiles as segmentation variable at selected arts festivals", unpublished M Com dissertation, North West University: Potchefstroom.

22 SAAYMAN, A. \& SAAYMAN, M. (2006) "Sociodemographics and visitor patterns of arts festivals in South Africa”, Event Management, 9(4): 211222.

23 SAAYMAN, A.; SAAYMAN, M. \& NAUDE, W. (2000) "The impact of tourists' spending in South Africa - spatial implications", paper prepared for the Regional Science Association International (RSAI) International Symposium on Regional Development in South Africa, Port Elizabeth Technikon, 25 January 2000, Port Elizabeth: 1-18.

24 SAAYMAN, M.; SAAYMAN, A. \& RHODES, J.L. (2001) "Domestic tourist spending and economic development: The case of the North West Province", Development Southern Africa, 18(4): 444-455, October.

25 SAAYMAN, M. \& VAN DER MERWE, P. (2006) "The economic contribution of biltong hunting in South Africa”, SA Hunters, March.

26 SAKAI, M.Y. (1988) "A micro-analysis of business travel demand", Applied Economics, 20(11): 14811495 . 
27 SEILER, V.L.; HSIEH, S.; SEILER, M.J. \& HSIEH, C. (2002) "Modelling travel expenditures for Taiwanese tourism", Journal of Travel and Tourism Marketing, 13(4): 47-59.

28 SKURAS, D.; DIMARA, E. \& PETROU, A. (2005) "Rural tourism and visitors' expenditure for local food products”, Regional Studies, 40(7): 767 779 , October.

29 SOUTH AFRICA ANNUAL TOURISM REPORT (2004) Provincial distribution, South African Tourism: Johannesburg.

30 VAN DER MERWE, P.; SAAYMAN, M. \& KRUGELL, W. (2004) "Factors that determine the price of game", paper presented at the $6^{\text {th }}$ International Wildlife Ranching Symposium, Wildlife as a Natural Resource, 6-9 July, Paris.

31 VAN DER MERWE, P.; SAAYMAN, M. \& KRUGEL, W. (2006) "Economic contribution of biltong hunters in South Africa”, paper presented at the $61^{\text {st }}$ International Atlantic Economic Conference, 15-19 March, Berlin.
32 VAN HEERDEN, A. (2003) "The economic impact of Aardklop national arts festival in Potchefstroom", Master's dissertation, North-West University: Potchefstroom.

33 VAN HOVEN, W. (2005) "Ecotourism and game ranching: why it works", paper presented at the Ecotourism South Africa Confex, 9-11 November, Johannesburg.

34 VAN DER LANS, I.A.; VAN ITTERSUM, K.; DE CICCO, A. \& LOSEBY, M. (2001) "The role of the region of origin and EU certificates of origin in the consumer evaluation of food products", European Review of Agricultural Economics, 30: 451-477. 